\begin{tabular}{|c|c|c|c|c|c|c|}
\hline \multirow{4}{*}{ Impact Factor: } & ISRA (India) & $=3.117$ & SIS (USA) & $=0.912$ & ICV (Poland) & $=6.630$ \\
\hline & ISI (Dubai, UAE & $=0.829$ & РИНЦ (Russia) & $=0.156$ & PIF (India) & $=1.940$ \\
\hline & GIF (Australia) & $=0.564$ & ESJI (KZ) & $=8.716$ & IBI (India) & $=4.260$ \\
\hline & JIF & $=1.500$ & SJIF (Morocco) & $=5.667$ & OAJI (USA) & $=0.350$ \\
\hline
\end{tabular}

\section{SOI: $1.1 /$ TAS DOI: $10.15863 /$ TAS International Scientific Journal Theoretical \& Applied Science}

p-ISSN: 2308-4944 (print) e-ISSN: 2409-0085 (online)

Year: 2019 Issue: $04 \quad$ Volume: 72

Published: 24.04.2019 http://T-Science.org
QR - Issue
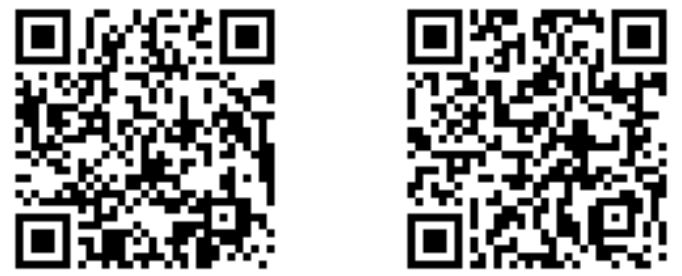

Sh.M. Ibatova

Samarkand State Medical Institute, Samarkand, Uzbekistan

N.Q. Muhamadiev

Samarkand State University, Samarkand, Uzbekistan

D.T. Rabbimova

Samarkand State Medical Institute, Samarkand,

Uzbekistan

E.S. Mamutova

Samarkand State Medical Institute, Samarkand,

Uzbekistan

N.B. Abdukadirova

Samarkand State Medical Institute, Samarkand,

Uzbekistan

M.M. Kadirova

Samarkand State Medical Institute, Samarkand,

Uzbekistan

\title{
GAS-CHROMATOGRAPHIC APPRAISAL OF APPLICATION OF APRICOT OIL AND AEVIT IN COMPLEX THERAPY OF VITAMIN D- DEFICIENCY RICKETS IN CHILDREN
}

Abstract: Significant disturbances in the metabolism of higher fatty acids have been revealed by the method of gas-liquid chromatography in children with vitamin D-deficiency rickets. Correction of impaired lipid metabolism by combined application of vegetable oil (apricot) and aevite was performed. The efficiency of the presented method of treatment is shown in the form of a table.

Key words: rickets, dismetabolism, fatty acids, apricot oil, Aevit, traditional treatment, modified method of treatment.

Language: English

Citation: Ibatova, S. M., Muhamadiev, N. Q., Rabbimova, D. T., Mamutova, E. S., Abdukadirova, N. B., \& Kadirova, M. M. (2019). Gas-chromatographic appraisal of application of apricot oil and aevit in complex therapy of vitamin D-deficiency rickets in children. ISJ Theoretical \& Applied Science, 04 (72), 333-336.

Soi: http://s-o-i.org/1.1/TAS-04-72-40 Doi: crossef https://dx.doi.org/10.15863/TAS.2019.04.72.40

\section{Introduction.}

In recent years, gas chromatography is one of the methods for determining markers of metabolic processes in the human body. In this regard, a special place is taken by fattyacids, the determination of which is easily carried out by gas-liquid chromatography.

We developed a technique for the determination of fatty acids under various pathological conditions, which includes the selection of a stationary phase [13]. Individual identification of the components of the mixture is carried out on the basis of structural-group components [13]. This technique was used to study the fatty acid composition of blood serum in children with pneumonia, hypotrophy, rickets and studied the features of lipid metabolism in patients with vesicovaginal fistula were studied [12]. The application of this technique to assess the 


\begin{tabular}{|c|c|c|c|c|c|c|}
\hline \multirow{4}{*}{ Impact Factor: } & ISRA (India) & $=3.117$ & SIS (USA) & $=0.912$ & ICV (Poland) & $=6.630$ \\
\hline & ISI (Dubai, UAE & $=0.829$ & РИНЦ (Russia) & $=0.156$ & PIF (India) & $=1.940$ \\
\hline & GIF (Australia) & $=0.564$ & ESJI (KZ) & $=8.716$ & IBI (India) & $=4.260$ \\
\hline & JIF & $=1.500$ & SJIF (Morocco & $=5.667$ & OAJI (USA) & $=0.350$ \\
\hline
\end{tabular}

effectiveness of the combined use of vegetable oil and antioxidants in the integrated treatment of rickets is relevant from the point of view of the choice of correction.

Rickets is not only a pediatric, but also a medical and social problem, the essence of which lies in the disturbance of the general metabolism, phosphoruscalcium, lipid metabolism, skeletal mineralization disorders and the functional state of internal organs and systems $[1-5,8,11]$.

Purpose of the study. Gas chromatographic evaluation of the use of apricot oil and Aevit in complex therapy of vitamin D-deficiency rickets in children.

\section{Material and methods of investigation.}

To fulfill this goal, we examined 87 patients with vitamin D-deficiency rickets in Children's Polyclinic No. 1 in Samarkand. The control group consisted of 16 practically healthy children.

The history was collected by interviewing parents of children with the introduction of the data into specially designed individual patient's cards. We assessed the somatic and obstetric-gynecological history of mothers, the family life conditions, the characteristics of the course of pregnancy, childbirth and the neonatal period, the nature of feeding, the state of specific prevention of vitamin D-deficiencyrickets. We took into account the dynamics of the massgrowth parameters of the child, the diseases that were transferred, the risk factors predisposing to the development of vitamin D-deficiency rickets, both from the mother and the child.

Clinical evaluation of the examined children with vitamin D-deficiency rickets was carried out on the basis of studying the general condition, musculoskeletal, nervous system and psychomotor development. Criteria for assessing the degree of hypotrophy were weight and height, taking into account the severity of the subcutaneous fat layer on the abdomen - at the level of the navel, the sequence of its decrease, turgor of tissues, skin color and visible mucous membranes, anthropometric data, taking into account the Chulick, Erisman and Tour indices.

The composition of higher fatty acids in the blood serum in children with vitamin D deficiency rickets was determined by gas-liquid chromatography $[7,9,10]$. To identify the separated methyl esters of fatty acids, the method of "witnesses" and the method based on the structural-group constituents "sorbentsorbate" [4] were used. As a result of identification in the serum, the following fatty acids were found: $\mathrm{C}(16: 0)$ - palmitic, $\mathrm{C}(16: 1)$ - palmitoleic, $\mathrm{C}(18: 0)$ stearic, C(18:1) - oleic, C(18:2) - linoleic, C(18:3) linolenic and $C(20: 4)$ - arachidonic. The content of fatty acids was determined by the method of internal normalization [9].

\section{Results of the study and their discussion.}

The patients were divided into 2 groups. I-group of children (38 patients) with rickets received a traditional method of therapy. The results of the study are presented in Table 1.

The II group of examined children with rickets (49 patients) received apricot oil and Aevit against the background of the traditional method of treatment. The results of the study are presented in Table 2.

The study of the composition of higher fatty acids in the blood serum in children with rickets (Group I - 38 patients with rickets) undergoing the traditional method of treatment (Table 1) and Group II (49 patients with rickets) in combination of the traditional method of treatment with the use of modified therapy was carried out (Table 2).

The results obtained to determine the content of higher fatty acids in blood serum of children with rickets in comparison with the data of healthy children are presented in Table 2 .

Table 1. Compound and content of fatty acids in blood serum of children with rickets.

\begin{tabular}{|c|c|c|c|}
\hline Fatty acids & Control & During research & P< \\
\hline C (16:0) & $28,17 \pm 1,37$ & $30,87 \pm 1,53$ & 0,01 \\
\hline C (16:1) & $2,70 \pm 0,22$ & $1,38 \pm 0,64$ & 0,05 \\
\hline C (18:0) & $26,13 \pm 1,32$ & $28,03 \pm 1,04$ & 0,01 \\
\hline C (18:1) & $0,90 \pm 0,13$ & $0.66 \pm 0,6$ & 0,05 \\
\hline C (18:2) & $33,32 \pm 2,51$ & $29,73 \pm 2,34$ & 0,01 \\
\hline C (18:3) & $2,41 \pm 0,45$ & $2,58 \pm 0,50$ & 0,01 \\
\hline C (20:4) & $3,56 \pm 0,60$ & $2,68 \pm 0,60$ & \\
\hline
\end{tabular}

Note: $\mathrm{P}$ - the reliability of the difference between the indicators in the group of patients and healthy persons. 


\begin{tabular}{|c|c|c|c|c|c|c|}
\hline \multirow{4}{*}{ Impact Factor: } & ISRA (India) & $=\mathbf{3 . 1 1 7}$ & SIS (USA) & $=0.912$ & ICV (Poland) & $=6.630$ \\
\hline & ISI (Dubai, UAE & $=0.829$ & РИНЦ (Russia) & $=0.156$ & PIF (India) & $=1.940$ \\
\hline & GIF (Australia) & $=0.564$ & ESJI (KZ) & $=8.716$ & IBI (India) & $=4.260$ \\
\hline & JIF & $=1.500$ & SJIF (Morocco) & $=5.667$ & OAJI (USA) & $=0.350$ \\
\hline
\end{tabular}

Table 2. The compound and content of fatty acids (in \%) in blood serum depending on the method of fatty acids treatment.

\begin{tabular}{|l|c|c|c|c|c|}
\hline \multirow{2}{*}{ Fatty acids } & Control & \multicolumn{4}{|c|}{ Method of treatment } \\
\cline { 3 - 6 } & & \multicolumn{2}{|c|}{ Traditional } & \multicolumn{2}{c|}{ Modified } \\
\cline { 3 - 6 } & & $\mathrm{M} \pm \mathrm{M}$ & $\mathrm{P}<$ & $\mathrm{M} \pm \mathrm{M}$ & $\mathrm{P}<$ \\
\hline & $28,17 \pm 1,37$ & $28,96 \pm 1,28$ & 0,01 & $28,21 \pm 1,31$ & 0,1 \\
\hline $\mathrm{C}(16: 0)$ & $2,70 \pm 0,22$ & $1,62, \pm 0,43$ & 0,01 & $2,55 \pm 0,30$ & 0.1 \\
\hline $\mathrm{C}(16: 1)$ & $26,13 \pm 1,32$ & $27,67 \pm 0,82$ & 0,20 & $26,75 \pm 0,80$ & 0,1 \\
\hline $\mathrm{C}(18: 0)$ & $0,90 \pm 0,13$ & $0,76 \pm 0,10$ & 0,20 & $0,92 \pm 0,10$ & 0,1 \\
\hline $\mathrm{C}(18: 1)$ & $33,32 \pm 2,51$ & $30,74 \pm 2,10$ & 0,50 & $33,12 \pm 1,80$ & 0,1 \\
\hline $\mathrm{C}(18: 2)$ & $2,41 \pm 0,45$ & $2,11 \pm 0,45$ & 0,05 & $2,73 \pm 0,45$ & 0,1 \\
\hline $\mathrm{C}(18: 3)$ & $3,56 \pm 0,60$ & $2,10 \pm 0.51$ & 0,05 & $3,26 \pm 0,40$ & 0,1 \\
\hline $\mathrm{C}(20: 4)$ & & & &
\end{tabular}

Notes: P- of relatively healthy children.

As can be seen from the data given in children with vitamin D deficiency rickets, the content of fatty acids such as palmitic, stearic and linoleic acids is increased, and palmitoleic, oleic, linolenic and arachidonic acids are reduced, i.e. there are disturbances of the studied indicators of lipid metabolism, which proves airmenaimpt of lipid metabolism in rickets. This dictates the need for correction of lipid metabolism in this pathology with the inclusion of vegetable oils.

For the selection of vegetable oil, we have estimated the digestibility of vegetable oils by the organism to lipase activity of blood serum. The conducted studies showed that the lipase activity of blood serum in the control group (10 children) was $10,2 \pm 3,6 \mu \mathrm{mol} /(1 \cdot \mathrm{min})$. When used in a diet of cottonseed oil, it was equal to $-10.5 \pm 4.1 \mu \mathrm{mol} /(1 \cdot \mathrm{min})$ $(n=25)$, i.e., there was no noticeable change in this group. When giving the rye oil, it was $16.8 \pm 4.2$ $\mu \mathrm{mol} /(1 \cdot \min ) \quad(\mathrm{n}=22)$, the sea-buckthorn oil was $18.9 \pm 3.7 \mu \mathrm{mol} /(1 \cdot \min )(\mathrm{n}=22)$, and when the children were given the apricot oil, the lipase activity of the blood serum increased significantly and amounted to $-20.7 \pm 3.9 \mu \mathrm{mol} /(1 \cdot \mathrm{min}) \quad(\mathrm{n}=18)$. From the data obtained, it can be seen that the use of apricot oil leads to 2 times improvement in the digestibility of lipids by increasing the activity of serum lipase and thereby improves the indices of lipid metabolism.

In this connection, apricot oil is used as a substance that corrects the disturbed lipid metabolism, as it is rich in polyunsaturated fatty acids, has a pleasant smell and taste, has a high biological activity and has a beneficial effect on metabolic processes in the child's body [5,6]. As an antioxidant Aevit was used.

In the examined children, the ill with rickets, who received traditional treatment, there was a wide range of fluctuations of the studied indicators of lipid metabolism.

In our opinion, the lipid imbalance is probably due to the fact that the effect of specific therapy in the body is primarily aimed at correcting the phosphoruscalcium metabolism, sonormalization of the studied indices of lipid metabolism did not take placethat required their further correction.

As can be seen from Table 2, performed method of treatment showed its high efficiency, which is confirmed by the obtained data: $\mathrm{C}(16: 0)-28.21 \pm$ $1.31 \%, \mathrm{C}(16: 1)-2.55 \pm 0,30 \%, \mathrm{C}(18: 0)-26.75 \pm 0.80 \%$, $\mathrm{C}(18: 1)-0.92 \pm 0.10 \%, \quad \mathrm{C}(18: 2) \quad-33.12 \pm 1.80 \% \quad$; C(18:3)-2.73 $\pm 0.45 \%$; C(20:4)-3.26 $\pm 0.40 \%$, i.e. under the influence of the modified treatment, the fat-acid compound parameters were normalized in the majority of patients.

\section{CONCLUSIONS.}

1. It was revealed that in children with rickets, there is a significant difference in the indices of individual fatty acids in comparison with those of healthy children.

2. In order to correct the dismetabolism of higher fatty acids, besides to traditional therapy, an additional prescription of apricot oil and Aevit is recommended, which ensures high effectiveness of therapy in children with rickets. 


\begin{tabular}{|c|c|c|c|c|c|c|}
\hline \multirow{4}{*}{ Impact Factor: } & ISRA (India) & $=3.117$ & SIS (USA) & $=0.912$ & ICV (Poland) & $=6.630$ \\
\hline & ISI (Dubai, UAE & $=0.829$ & РИНЦ (Russia & $=\mathbf{0 . 1 5 6}$ & PIF (India) & $=1.940$ \\
\hline & GIF (Australia) & $=0.564$ & ESJI (KZ) & $=8.716$ & IBI (India) & $=4.260$ \\
\hline & JIF & $=1.500$ & SJIF (Morocco & $=5.667$ & OAJI (USA) & $=0.350$ \\
\hline
\end{tabular}

\section{References:}

1. Pludowski, P., et al. (2018). Vitamin D supplementation guidelines. The Journal of steroid biochemistry and molecular biology Vol. 175, pp. 125-135.

2. Zakharova, I. N., et al. (2011). Rickets and D hypovitaminosis - a new look at a longstanding problem. A manual for doctors. (P.96). Moscow.

3. Zakharova, I. N., et al. (2010). The role of metabolites of vitamin D in rickets in children. The Journal Pediatrics, Vol. 89, No. 3, pp.68-73.

4. Ibatova, S. M., et al. (2013). Apricot oil as a regulator of lipase activity of blood serum in children with vitamin D deficiency rickets. The Journal Problems of Biology and Medicine, No. 4, pp. 138-139.

5. Mukhamadiev, N. K., et al. (2000). Gas chromatographic estimation of fatty acids in blood sera of children, ill with rickets. PRACI 2nd Ukranian symposium on adsorption and chromatography. (pp.211214). Lviv.

6. Neudakhin, E. V., \& Ageykin, A. V. (2003). Controversial theoretical and practical questions of rickets in children at the present stage. The Journal Pediatrics, N4, pp. 95-98.

7. Muhamadiev, N. Q., et al. (2007). BIOL 249"Study of fatty-acid composition of blood serum in children with vitamin D-deficient rachitis by the method of gas-liquid chromatography". Abstracts of papers of the American Chemical Society. - 1155 16TH ST, NW. Washington, DC USA: Amer Chemical Soc, Vol. 234.

8. Ibatova, S. M., et al. (2015). Improvement of Vitamin-D deficient rachitis treatment in children. International Journal of Medicine \& Health Research Vol. 1, No. 1, pp. 1-5.

9. Zakharova, I. N., \& Dmitrieva, Y. A. (2010). Vitamin D metabolism in children with rickets. Trace elements in medicine Vol.ll, No 2, p.39.

10. Mukhamadiev, N. Q., et al. (2003). Optimization of the separation on the basis of unifac parameters and evaluation of the composition of the stationary phase in gasliquid chromatography. Chromatographia, Vol. 57, No. 11-12, pp. 831-833.

11. Ibatova, S., et al. (2018). Correction of some lipid metabolism in children with rickets by the combined use of apricot oil and aevita". Proceedings of the XXXIV International Scientific and Practical Internet Conference "Trends and Prospects for the Development of Science and Education in the Context of Globalization". Collection of scientific papers Pereyaslav-Khmelnitsky, pp. 589593. 